Chapter 4

\title{
Entrepreneurship Education in Spain
}

\author{
José C. Sánchez-García and \\ Brizeida Hernández-Sánchez \\ Additional information is available at the end of the chapter \\ http://dx.doi.org/10.5772/58978
}

\section{Introduction}

The study of entrepreneurship at all stages of education has been the subject of debate in the international sphere for many years. For some time now the European Union has been recommending its member States to carry out specific actions in order to foster an enterprising spirit among students. Currently some very important documents and recommendations for action are available, and they call on public authorities, business associations, schools, NGOs and other interested parties to promote entrepreneurship in education.

Although numerous studies have shown that business skills can be cultivated as early as the first stages of schooling and that there is a strong relation between an adequate educational offering in entrepreneurship and greater business activity, the truth is that the educational training in entrepreneurship offered is still poor in all countries, especially at the pre-university level [1-6]

The aim of this chapter is to present concrete experiences of the practical application of entrepreneurship education in Spain and also to contribute to the dissemination and exchange of best practices in that country. In doing so we hope to offer a complete panorama of the current situation in Spain and help to design future actions. We also hope this serves as a stimulus to highlight all of these experiences.

\subsection{International framework: OECD and EU}

At the European level, entrepreneurship education has mainly been approached from international agencies such as the Organization for Economic Cooperation and Development (OECD) and the European Union (EU), of which Spain is a member. 
The OECD groups 30 States committed to promoting democracy and a market economy. It came into being in 1961 as the successor of the Organization for European Economic Cooperation (OEEC). The OECD compiles statistics and comparative economic data; it investigates social change and developmental patterns in areas such as commerce, the environment, agriculture and other sectors. In this way its member States can compare experiences and seek effective solutions to problems that are common to all. In the fields of education and employment, the OECD is not only working hard to ensure equal access to education but also fighting against social exclusion and unemployment.

Among the milestones in fostering an enterprising spirit we would highlight the Bologna Conference and the Istanbul Conference. On June 14-15, 2000, the $1^{\text {st }}$ Ministerial Conference was held in Bologna to discuss "Enhancing the Competitiveness of SMEs in the Global Economy: Strategies and Policies," thus giving rise to the so-called Bologna Process on SME policies and entrepreneurship. The result of that conference was the Bologna Charter on SME Policies in 2000 [4], which proposed a consistent approach to SME policies. The Charter recommends that SME policies should take into account that the capability of these companies to manage innovation can be improved by: the dissemination of a culture of innovation, and the dissemination of technological and market information (e.g. by creating links between companies and educational systems).

The OECD Ministerial Conference held in Istanbul on June 3-5, 2004 to discuss "Promoting Entrepreneurship and Innovative SMEs in a Global Economy" examined how to promote entrepreneurship as a force for innovation, as well as the effects of globalization on SMEs and their ability to compete globally. The Ministerial Declaration from the Istanbul Conference regarding the promotion of innovative and internationally competitive SMEs reaffirms the need to support the development of the best public policies, including education, in order to foster the creation and rapid growth of innovative SMEs. It specifically proposes the development of a culture that favours entrepreneurship and recognizes successful businesses as well as the integration of entrepreneurship at all levels of the formal education system to facilitate this development. Formal education should be complemented with "learn by doing" activities and other practical workshops; this objective thus demands special attention to teacher training programs.

In regard to the European Union (EU), it should be pointed out that the treatment of entrepreneurship education in the European context has its origins in several different authorities. First, the European Commission, through the Directorate-General for Enterprise and Industry (DG Enterprise and Industry), which is in charge of promoting the agenda of entrepreneurial initiative, including in education, by means of political cooperation outside the structure of binding Community legislative instruments. This matter has also been addressed by the DG of Education and Culture and in the DG for Regional and Urban Policy. Entrepreneurship education has thus been subject to consideration in the different agencies of the Council of Europe, and in the mandatory European Council meetings every semester.

The reasons why entrepreneurship education has been approached from such different angles in the EU are obvious. The DG of Education and Culture seeks to have comparable qualifications in order to foster the free circulation of persons and workers. The DG for Enterprise and 
Industry seeks to promote a business mentality and enrich the productive fabric of Europe. Both of these touch on regional cohesion policies, addressed to eliminating the differences in economic development of the member States and their regions.

Table 1 provides a synthesis of the main milestones in the European debate about the introduction of entrepreneurship education, from the year 2000 with the launching of the Lisbon strategy until the present. More information can be found regarding some of the milestones and documents included in the Table as well as how entrepreneurship education is treated in the EU by consulting the corresponding section of the SME portal of the European Commission [7].

\begin{tabular}{|c|c|c|}
\hline Document/ Event & Date & $\begin{array}{l}\text { Area of Community } \\
\text { Competence }\end{array}$ \\
\hline Special Meeting of the European Council in Lisbon & Lisbon, June 2000 & European Council \\
\hline European Charter for Small Enterprises & $\begin{array}{l}\text { Santa Maria da Feira, June } \\
2000\end{array}$ & EU General Affairs Council \\
\hline European Forum. Training for Entrepreneurship & Nice, October, 2000 & $\begin{array}{l}\text { DG Enterprise and Industry } \\
\text { (European Commission) }\end{array}$ \\
\hline Communiqué "Education and Training" & 2003 & European Commission \\
\hline $\begin{array}{l}\text { Communiqué "Promoting an enterprising mind-set } \\
\text { through education and training" }\end{array}$ & 2006 & European Commission \\
\hline $\begin{array}{l}\text { Conference "Entrepreneurship Education in Europe: } \\
\text { Fostering Entrepreneurial Mindsets through Education } \\
\text { and Learning" (Oslo Agenda) }\end{array}$ & Oslo, 2006 & European Commission \\
\hline $\begin{array}{l}\text { Recommendation on key competences for permanent } \\
\text { learning }\end{array}$ & 2006 & $\begin{array}{l}\text { European Parliament and } \\
\text { European Council }\end{array}$ \\
\hline “Small Business Act” for Europe (SBA) & June 2008 & European Commission \\
\hline \multirow[t]{5}{*}{$\begin{array}{l}\text { High level panels with representatives from the DGs } \\
\text { of Education and Industry/Economics } \\
\text { of the Member States }\end{array}$} & March to October 2009 & $\begin{array}{l}\text { European Commission and } \\
\text { Member States }\end{array}$ \\
\hline & November, 2009 & European Commission \\
\hline & November, 2011 & European Commission \\
\hline & March,2012 & European Commission \\
\hline & Marchb, 2012 & European Commission \\
\hline
\end{tabular}

Table 1. Summary of the principal milestones in the European debate on entrepreneurship education (2000-2012)

The debate in Europe began with the Special Meeting of the European Council in Lisbon, 2000 [8] to examine the development of entrepreneurship education in the EU agenda. The European Council meeting held on 23-24 March 2000 adopted the goal of making the EU's knowl- 
edge-based economy the most competitive and dynamic in the world, capable of sustainable economic growth, with more and better jobs and greater social cohesion, by 2010. As a means to achieving this objective it was agreed, among other things, that it was necessary to create the best possible environment for small businesses and entrepreneurship. The European Charter for Small Enterprises, also known as the Feira Charter [9], was subsequently adopted by the Council of General Affairs in Lisbon on 13 June 2000, and was approved at the European Council Meeting at Santa María da Feira, held on 19-20 June of that same year. The Charter recommends that member State governments should concentrate their strategic efforts around ten lines of action of capital importance for the context in which small businesses operate.

Among these lines of action, the most outstanding, in the first place, is education and learning for entrepreneurship, since in order to cultivate an enterprising spirit from an early age it is necessary to offer studies relating to the business sphere, mainly at the secondary and university levels, and foster both the business initiatives of young people and educational programmes addressed to small businesses.

In addition, the DG Enterprise and Industry of the European Commission, in conjunction with EU member States, organized the Niva Sophia Antipolis Forum in Training for Entrepreneurship in October 2000 [10], which brought together 350 representatives from a wide range of educational agencies and institutions and local development initiatives, national representatives and representatives from the business world and business organizations. Debates were structured around three workshops:

1. From school to university: what teaching and learning strategies, what action should be taken to encourage the entrepreneurial spirit in young people?

2. How can vocational training promote entrepreneurial initiative?

3. New management practices and the development of "intrapreneurship".

As a result of these workshop debates a report was written highlighting the following as educational goals, especially at the lower level (primary and secondary):

- Fostering pupils' and students' problem-solving capabilities. This should improve their ability to plan, make decisions and communicate, as well as making them more willing to take on responsibilities, i.e. the typical aspects of management competencies.

- Pupils and students should become ever more able to cooperate, network, take on new roles, etc. In other words, the aspects typical of social competencies should be fostered.

- Pupils and students should develop self-confidence and a motivation to act, learn to think critically and independently, and in particular, acquire the will and the ability to learn autonomously, that is, personal competencies.

- Pupils and students should acquire a thirst for creativity, proactivity, and personal initiative, as well as be prepared to face risks when their ideas are put into practice, that is, what are known as typical enterprising qualities.

Moreover, the IV Multiannual Programme Fostering Enterprise and Entrepreneurship 2001-2005, approved by Council Decision of 20 December 2000 [11], considers a compilation 
of reports of best practices following the methodology known as "best procedure". This methodology consists of applying the Open Method of Coordination (OMC) -stipulated in the Lisbon Strategy as the work methodology - for the specific context of SME support policies [12].

Among the activities of the Multiannual Programme in question, the European Commission has published three reports on the introduction of entrepreneurship into non-university education, based on the aforementioned methodology of the exchange of best practices. Experts from all of the member States have contributed to identifying the best practices for these reports. The contact point in Spain for the designation of experts is the DGPYME (DG for SMEs), which has named the experts proposed by the Spanish Ministry of Education and Science in all these groups.

The contents of these reports can be summarized as follows:

1. The first report was published in 2002 under the title "Final Report of the Expert Group on Education and Learning for Entrepreneurship" [13] and deals with key aspects in fostering an enterprising spirit in Primary and Secondary Education: teacher training in entrepreneurship; cooperation between schools and universities, on the one hand, and between schools and businesses, on the other, addressed to promoting an entrepreneurial spirit; university chairs in entrepreneurship and the activities they organize. In addition, they came to a common agreement on the definition of entrepreneurship or "enterprising spirit" that contains two elements:

- A broad concept of education in enterprising attitudes and capabilities, which includes the development of certain personal qualities and does not focus directly on enterprise creation,

- A specific concept of education addressing enterprise creation.

The recommendations of the expert group included organizing a "European Day of Entrepreneurship Education" and the creation of permanent networks of experts on this matter; an enhancement of efforts to compile quantitative data, including the adoption of national action plans; better offers of specific training for teachers; greater promotion of existing international programmes based on learning through practice ; the creation of a national or regional framework for entrepreneurship education and the realization of political commitments.

2. Subsequently, in 2004 [14], based on the recommendations of the abovementioned report, a new document was published by the expert group on entrepreneurship education in primary and secondary education, in which they identified the national and regional policies capable of fostering concrete advances in entrepreneurship education in primary and secondary schools. In addition to analysing the national curriculum, the report compiled data and recommended putting support measures into effect at both the national and European level, and pointed out the importance of establishing stable links with the Administration, especially the Ministries of Education and Economy/Industry. The group's report also calls on regional and local authorities, as well as business associations.

3. The third report, entitled "Final Report of the Expert Group on Mini-Companies in Secondary Education", published in 2005 [15], focused on mini-companies as an effective 
methodology for disseminating an entrepreneurial mind-set. This project made an inventory of student business programmes in secondary schools, based on information contributed by the member States. It also adopted the term "mini-company" or "student company" as a "pedagogical tool based on practical experience by means of running a complete enterprise project, and on interaction with the external environment (i.e. the business world or the local community)" either with real cases or virtual simulations.

The expert group identified certain factors for the effectiveness and success of these student enterprises, such as contact with the local business community, the adaptability of these programmes to different types of education and students'enthusiasm or motivation. They also recommended that these mini-companies (also known as student companies) should be present in educational systems. More specifically, public authorities were recommended to:

- develop a general strategy for teaching entrepreneurship in schools;

- establish permanent cooperation among the different ministries, business associations, NGOs, educational institutions and municipalities in order to foster activities based on the student company methodology;

- approve and actively promote student companies in schools and among heads and teachers;

- guarantee the elimination of legal and administrative barriers to the creation and implementation of mini-companies.

The European Commission's Communiqué of 11 November 2003, Education and Training 2010 [16], recognizes the efforts made by the member States to adapt educational and training systems to the knowledge society and economy, but urges them to increase the rhythm of the reforms and to adopt a global, consistent and concerted strategy.

In 2006, The European Commission's Communiqué of 13 February entitled "Promoting an enterprising mind-set through education and training"' [17] supports the member States in developing a more systematic strategy for entrepreneurship education.

The continuation of this Communiqué gave rise to the Conference held in Oslo on 26-27 October 2006 regarding "Entrepreneurship Education in Europe: Fostering Entrepreneurial Mind-sets through Education and Learning" [18], convened by the Commission together with the Norwegian government, and the result of which was the Oslo Agenda for Entrepreneurship Education in Europe. This is the next milestone after the Feira Charter in the development of entrepreneurship education in the EU.

During the Conference, representatives of the different national, regional and local governments, business associations, teachers and students, NGOs and the Commission itself exchanged examples of best practices and proposals were launched to advance in this matter at all levels of education, from Primary School to University.

The conclusions of the Conference advocated better integration of the programmes and activities within the curricula, while maintaining flexibility as to their contents and participants. Entrepreneurship can be integrated into the curricula as a horizontal element in all study 
contexts or as an independent subject. In any case the Conference conclusions recommend introducing new pedagogical methods in all subjects.

The conclusions also underscored the need to create a common European platform for projects in operation and teaching materials that will contribute to the dissemination of information and facilitate comparative analyses. Teacher mobility in this sense should be supported throughout Europe. In addition, they consider that the participation of individuals with business experience must be a basic element in entrepreneurship education, and that cooperation between the public and private sectors should be increased, involving companies as part of their corporate social responsibility. This participation on the part of companies should be recognized with some kind of prize awarded at the European level.

At national level the creation of guide groups is recommended, complemented by a European observatory in which all interested parties are represented (public administrations, companies, schools, students, etc.). The role of the observatory would be to determine the objectives of entrepreneurship education, taking into consideration its different elements.

The European Commission, again according to these conclusions, should take the initiative when assessing programmes and activities to ensure that the outcomes can be compared. In particular, it should support research into the impact of activities based on student minicompanies and specific business projects.

All of this was included in the Oslo Agenda for Entrepreneurship Education in Europe 2006, which is a proposal to take a step forward in fostering entrepreneurship in education through systematic and effective actions. The agenda contains a rich menu of educational options addressed to those in charge at different levels of action so that they can choose the most suitable options for them from among those proposed and adapt them to their specific situation.

These proposals were drawn up around six spheres of action: the framework of political development, support for schools, support for teachers and educators, entrepreneurship activities in schools and higher education, building networks and opening up education to the outside world, and communication activities [19].

The Recommendation of the European Parliament and Council of 18 December 2006, regarding the key competencies for permanent education [20] follows the Oslo Agenda chronologically.

According to this Recommendation, the key competencies for life-long learning comprise a combination of knowledge, skills and attitudes that are necessary for personal development, social integration, active citizenship and employment. They are essential for the knowledge society as a whole, and guarantee greater flexibility in the labour market, allowing it to adapt to the constant changes taking place in a globalized world. Young people should acquire these competencies by the end of their compulsory education and training, such that they are capacitated for adult life and the working world.

The Recommendation defines eight key competencies [21], and describes the knowledge, skills and attitudes that each of them comprises. They are listed below: 
1. Communication in one's native language

2. Communication in foreign languages

3. Mathematical competencies and basic competencies in science and technology

4. Digital competency

5. Learning how to learn

6. Social and civic competencies

7. Sense of initiative and entrepreneurship

8. Cultural awareness and expression

All of these competencies are interdependent and all of them stress critical thinking, creativity, initiative, problem-solving, risk-assessment, decision-making and the constructive management of emotions. Number seven, the sense of initiative and entrepreneurship, is defined as the ability to put ideas into action. It presupposes creativity, innovation and risk-taking, as well as the ability to plan and manage projects in order to attain objectives. The subject is aware of his or her work environment and is able to take advantage of the opportunities that arise.

Another outstanding milestone in the EU context is the Small Business Act (SBA) of June 2008 [22]. In a Communiqué, the European Commission includes ten principles to guide the formulation and execution of policies for improving the legal and administrative framework of small and medium sized businesses in the EU and its member States. Its full title is "Think Small First - "A Small Business Act" for Europe: An initiative in favour of small enterprises". The Communiqué recognizes that the role of SMEs in our society is becoming more and more important, as they create employment and are key protagonists in guaranteeing the prosperity of local and regional communities.

Among its ten principles it first highlights precisely the one that involves actions relating to entrepreneurship education: "Create an environment in which entrepreneurs and family businesses can thrive and entrepreneurship is rewarded". In this sense the EU and member States wished to provide more support for future entrepreneurs, especially by stimulating entrepreneurial talent and interest, above all in women and young people.

After adoption of the SBA, The European Commission is making a new effort to improve the introduction of entrepreneurial initiative in the educational systems of all the member States. To do so, the DG Enterprise/Industry and the DG Education/Culture jointly organized a series of high level panels to bring together representatives from member States' Ministries of Education and Industry. These panels met in 2009 by groups of countries.

Our review of the principal milestones, events and reports from the European Union in this matter concludes with the report and assessment of the pilot action by the four high-level panels held in 2009. The report commissioned by the European Commission and entitled “Towards Greater Cooperation and Coherence in Entrepreneurship Education from March 2010, includes the successful outcomes attained and the goals that still remain to be achieved in order to develop this subject matter in a uniform way throughout all EU territory. 
As can be seen, the European debate regarding policies supporting SMEs and entrepreneurship is conceding well-deserved importance to education and training, and in the near future new European actions and programmes will be proposed to provide them with more momentum.

\section{Promoting entrepreneurship education in Spain}

Spain's Ministry of Education is charged, among other things, with the general programming of the educational system, the minimum curricular contents, and defining educational standards. For its part, the Ministry of Industry, responsible for policies supporting SMEs and enterprise creation, is charged with the dissemination and follow-up of Community directives for policies in support of entrepreneurship; it also carries out actions for fostering and promoting entrepreneurial initiative, sometimes in collaboration with the Ministry of Education, in fulfilment of Spain's 2006 Plan for Business Promotion. Added to these difficulties in coordination is the fact that, in Spain, powers in education have been transferred to the corresponding Autonomous Communities into which the country is divided (Figure 1), making it even more difficult to establish joint and unified programmes in regard to entrepreneurship education.

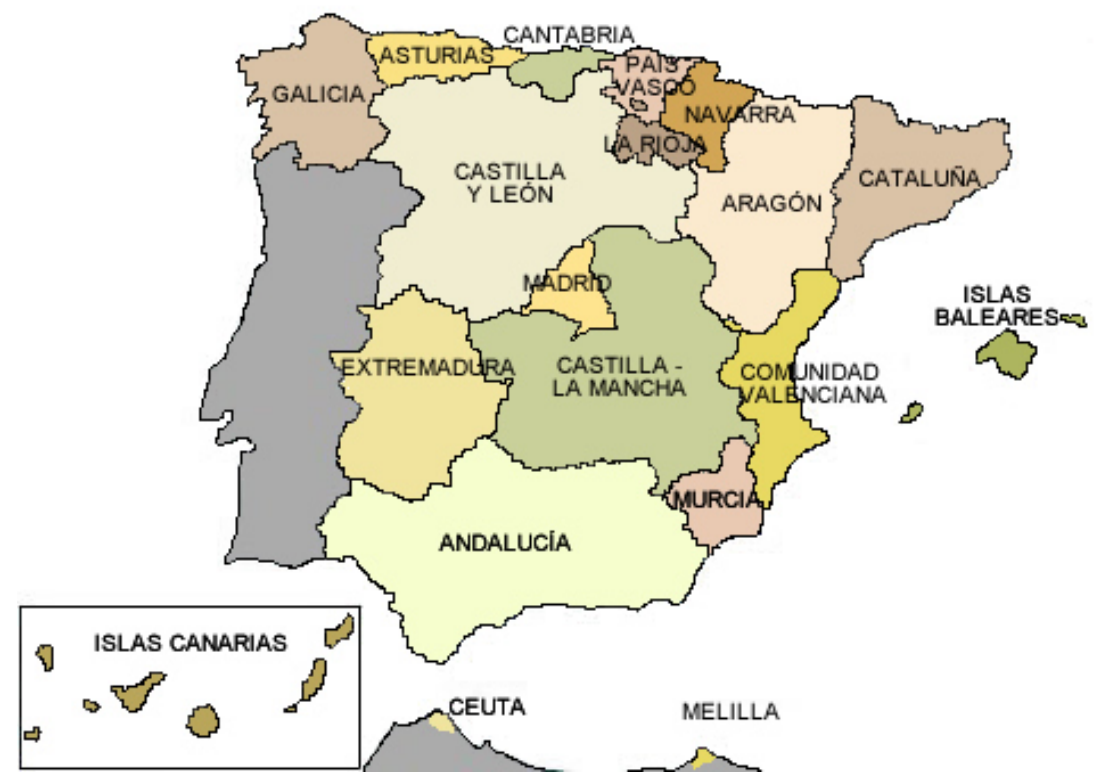

Figure 1. Autonomous Communities of Spain 
In 2003 Spain's DG for SMEs held a series of institutional contacts with the Ministry of Education with the idea of including entrepreneurial initiative as a basic competency to be attained in education, and to name experts from that Ministry to the work groups and meetings on the matter organized by the European Commission's DG of Enterprise and Industry. Likewise, Spain's DG for SMEs informed the EU of the best practices that, in this aspect, were beginning to be developed in Spain, underscoring the case of Valnalón in Asturias.

Since then, this DG has continued systematically to disseminate the European directives in this matter in order to incorporate this European objective as a basic aspect of Spanish public policies, both in the General State Administration and in the Autonomous Communities, and has continued to keep the EU informed of the most important Spanish experiences in this sense. With the reform of Constitutional Act 2/2006, of 3 May, of Education (LOE), the DG for SMEs again worked together with the Ministry of Education to ensure that entrepreneurial initiative was included in the Act as one of the major basic goals of the educational system, a matter which in the end was indeed included in the LOE. Both Ministries have also collaborated on the development of curricular contents in the different types of education. Since then, and up until now, the different laws and regulations relating to education have tried to spotlight the importance of this topic, which has now been officially introduced into the Royal Decrees on Teaching.

Nonetheless, even before the LOE was passed, quite a few enterprise-creating initiatives had been developing for some years in secondary and vocational schools in many of Spain's Autonomous Communities: Asturias, Extremadura, Galicia, etc. Some of them collaborate with each other and share educational methodologies and materials, as is the case of the EJE and EME programmes created by Valnalón in Asturias and implemented in many other Autonomous Communities.

Other important work that must be mentioned is that carried out by the Junior Achievement Foundation [23] since its establishment in Spain in 2001. Junior Achievement collaborates directly with schools all over Spain to prepare and inspire young people to be successful in a global economy by generating an entrepreneurial mind-set through different educational activities and competitions.

The compilation of these and other experiences is based on the publication, "Fostering an Entrepreneurial Mind-set in Schools" (Spanish Higher Council of Chambers of Commerce and the Ministry of Education, Social Policy and Sport - 2009), which contains an analysis of the situation in Spain, reflecting certain experiences and best practices in education, and the works by Sánchez, et al $[1,4]$. These references have helped to identify existing best practices and they have been thoroughly and systematically updated, taking into account the new normative framework. For this task, the information used was provided by the different Regional Ministries of Education, Industry and Labour of Spain's Autonomous Communities, as well as information supplied by Chambers of Commerce and European Centres for Enterprise and Innovation.

We now move on to the entrepreneurship initiatives carried out in Spain by its Autonomous Communities. Some projects had to be left out because they are just getting started, and there 
may be others that as yet we have been unable to detect. This first sample of programmes and activities, however, can serve as a summarized and synthesized approach to the situation of entrepreneurship education in Spain, classified by Autonomous Regions. Table 2 lists the main entrepreneurship education programmes that are still currently in force in each of the Autonomous Communities. The column marked "Results" specifies the number of schools involved and the number of students that participated during the last year for which data is available, usually 2010.

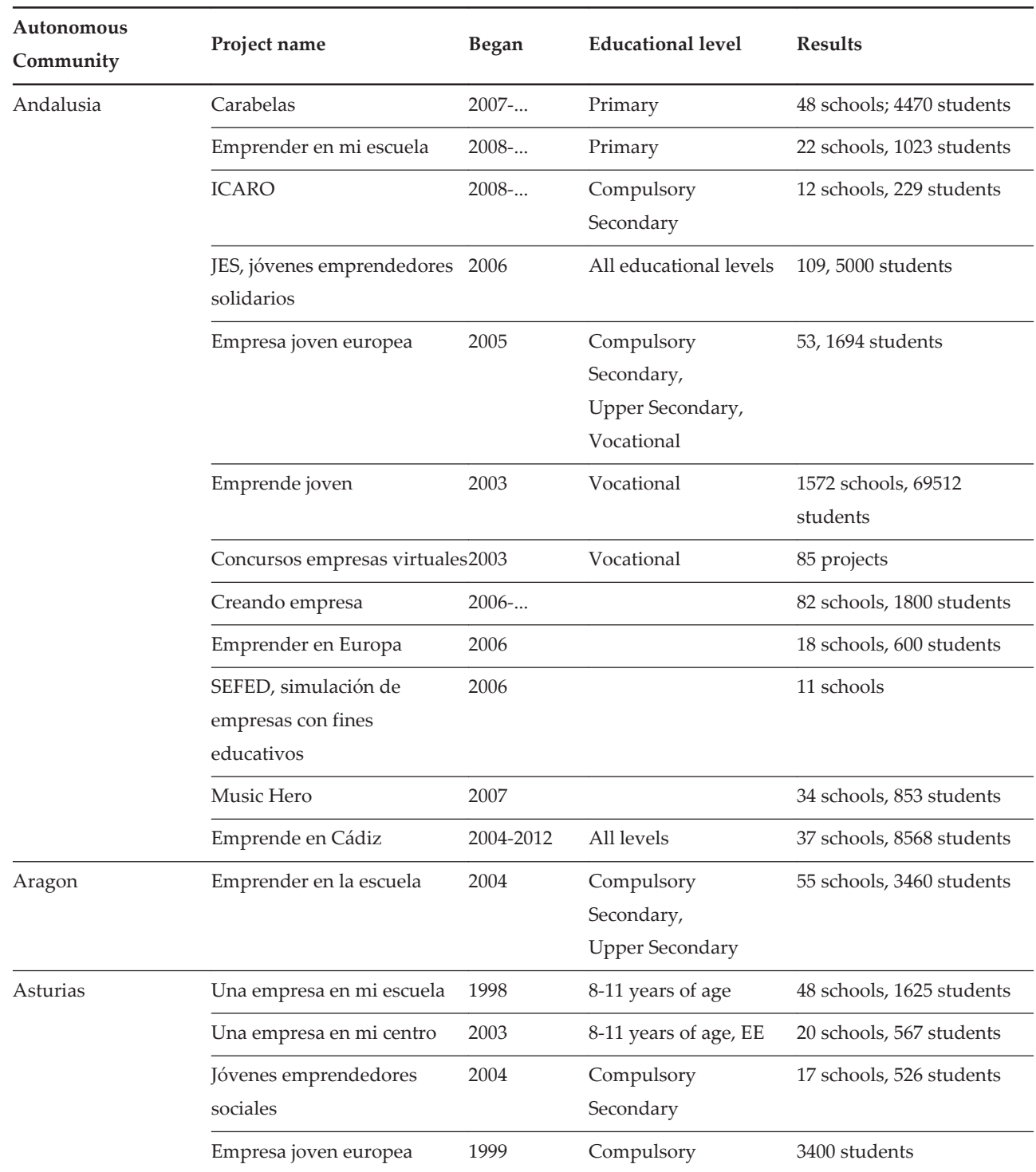




\begin{tabular}{|c|c|c|c|c|}
\hline $\begin{array}{l}\text { Autonomous } \\
\text { Community }\end{array}$ & Project name & Began & Educational level & Results \\
\hline & \multicolumn{4}{|c|}{ Secondary } \\
\hline & Eje profesional & 2005 & Vocational & 3400 students \\
\hline & Taller de Empresarios & 1994 & $17-25$ years of age & 9000 students \\
\hline & Jóvenes Productoras & 2003 & & 100 students per year \\
\hline & Cinematográficas & & & \\
\hline & $\begin{array}{l}\text { Creación y gestión de } \\
\text { microempresas }\end{array}$ & 2004 & Upper Secondary & 400 students \\
\hline \multirow[t]{3}{*}{ Balearic Islands } & Jornadas de autoocupación & 2002 & Vocational & 25 schools, 850 students \\
\hline & Crea Institut Empresa & 2008 & Vocational & \\
\hline & Simulación de Empresas & 2002 & Vocational & 15 schools, 640 students \\
\hline Canary Islands & $\begin{array}{l}\text { Una empresa en mi escuela, } \\
\text { EME y EJE }\end{array}$ & 2003 & $\begin{array}{l}\text { Compulsory } \\
\text { Secondary, } \\
\text { Vocational }\end{array}$ & \\
\hline \multirow[t]{4}{*}{ Cantabria } & Labor ESO & 2005 & \multicolumn{2}{|l|}{ Compulsory Secondary } \\
\hline & Simulación de empresas & & Vocational & \\
\hline & Cultura emprendedora & & Compulsory Secondary & \\
\hline & $\begin{array}{l}\text { Escuela juventud } \\
\text { emprendedora }\end{array}$ & 2006 & & 600 students \\
\hline \multirow[t]{3}{*}{ Castile-La Mancha } & Emprender en el aula & 2006 & \multicolumn{2}{|l|}{ Compulsory Secondary } \\
\hline & Innova Junior & 2007 & \multicolumn{2}{|l|}{$\begin{array}{l}\text { Compulsory } \\
\text { Secondary, Vocational, } \\
\text { Upper Secondary }\end{array}$} \\
\hline & $\begin{array}{l}\text { Jornadas de creación de } \\
\text { empresas }\end{array}$ & 1999 & Upper Secondary, FP & $\begin{array}{l}240 \text { workshops, } 6667 \\
\text { attendees }\end{array}$ \\
\hline \multirow[t]{5}{*}{ Castile-Leon } & Vitamina E-Primaria & 2007 & Primary & 26 schools, 236 students \\
\hline & Vitamina E-Iniciativa & 2004 & Compulsory & 123 schools, 2420 students. \\
\hline & Emprendedora & & Secondary $\left(4^{\text {th }} y r\right.$. $)$ & \\
\hline & Vitamina E-Upper Secondary & 2007 & Upper Secondary & 293 schools \\
\hline & Aprende a emprender & 2002 & Vocational & 193 schools, 14000 students \\
\hline \multirow[t]{3}{*}{ Cataluña } & $\begin{array}{l}\text { Seminarios de generación de } \\
\text { ideas }\end{array}$ & 2007 & $\begin{array}{l}\text { Compulsory } \\
\text { Secondary, } \\
\text { Upper Secondary }\end{array}$ & $\begin{array}{l}119 \text { seminars, } 53 \\
\text { workshops }\end{array}$ \\
\hline & Programa emprendedores & 2007 & $\begin{array}{l}\text { Compulsory } \\
\text { Secondary }\end{array}$ & 37 schools \\
\hline & Estada a l'empresa & & Upper Secondary & \\
\hline
\end{tabular}




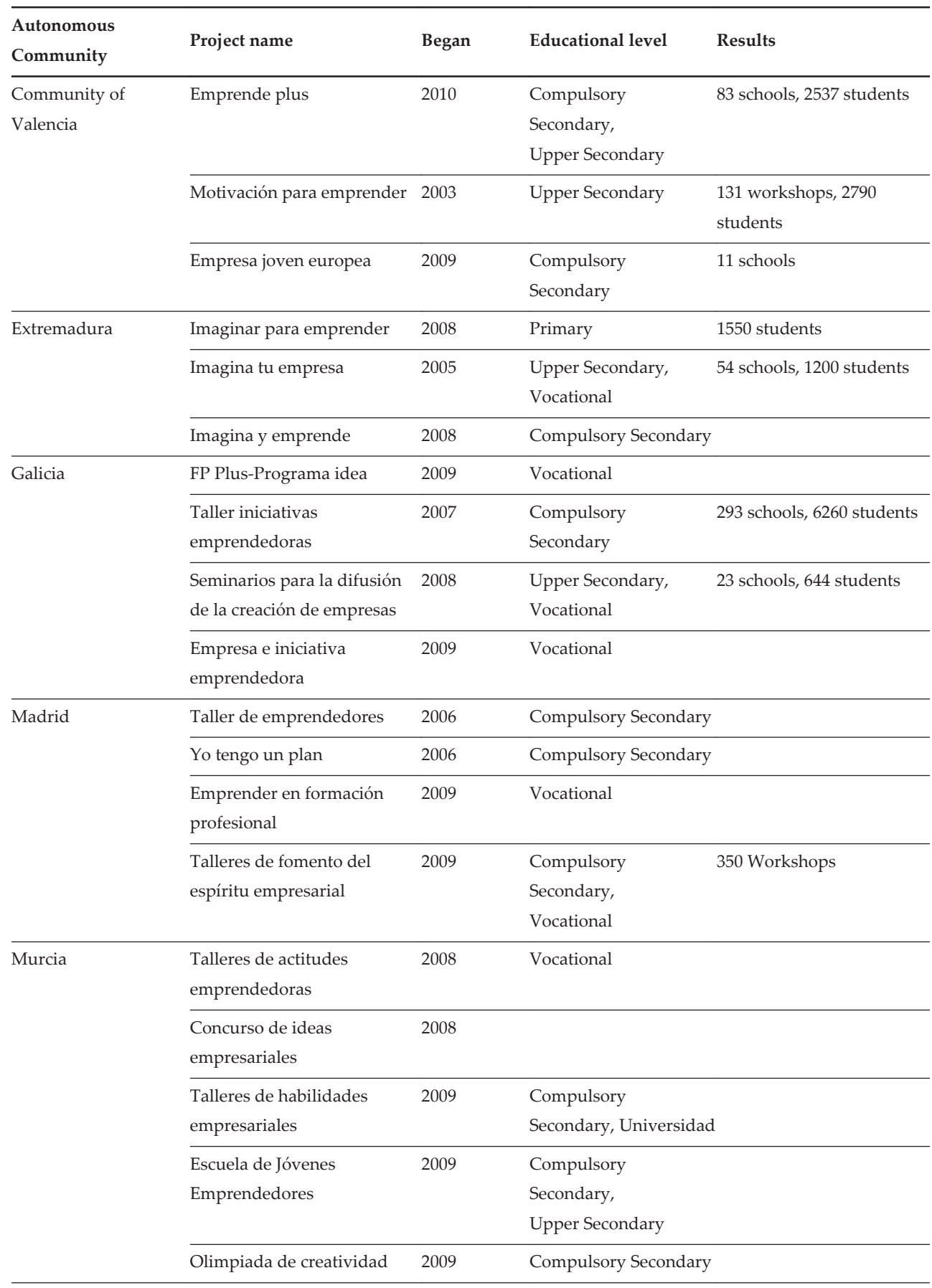




\begin{tabular}{|c|c|c|c|c|}
\hline $\begin{array}{l}\text { Autonomous } \\
\text { Community }\end{array}$ & Project name & Began & Educational level & Results \\
\hline \multirow[t]{4}{*}{ Navarre } & \multicolumn{2}{|l|}{ Empresa Joven Europea } & \multicolumn{2}{|l|}{ Compulsory Secondary } \\
\hline & \multicolumn{2}{|l|}{ Guía-activa FP } & \multicolumn{2}{|l|}{ Vocational } \\
\hline & \multicolumn{2}{|l|}{ Concurso Jóvenes } & \multicolumn{2}{|l|}{ Vocational } \\
\hline & \multicolumn{2}{|l|}{ Emprendedores } & & \\
\hline \multirow[t]{9}{*}{ Basque Country } & Hasi eta hazi primaria & 2007 & \multicolumn{2}{|l|}{ Primary } \\
\hline & Hasi eta hazi secundaria & 2007 & \multicolumn{2}{|l|}{ Compulsory Secondary } \\
\hline & Hasi eta hazi Bachillerato & 2007 & \multicolumn{2}{|l|}{ Upper Secondary } \\
\hline & \multirow[t]{3}{*}{ Kosmodisea } & \multirow[t]{3}{*}{2006} & Primary, Compulsory & 40 schools, 5430 students \\
\hline & & & \multicolumn{2}{|l|}{ Secondary, Upper } \\
\hline & & & \multicolumn{2}{|l|}{ Secondary } \\
\hline & Gaze & 2008 & University & 1000 students \\
\hline & Sensibilización & 2008 & Vocational & 30 schools, 3000 students \\
\hline & Urratsbat & 2008 & Vocational & 40 schools \\
\hline \multirow[t]{5}{*}{ Rioja } & \multirow{2}{*}{\multicolumn{2}{|c|}{$\begin{array}{l}\text { Olimpiada de } \\
\text { emprendedores }\end{array}$}} & \multicolumn{2}{|l|}{ Vocational, Upper } \\
\hline & & & \multicolumn{2}{|l|}{ Secondary } \\
\hline & Concurso ideas de negocio & 2004 & Vocational & 104 ideas presented \\
\hline & Empresa joven educativa & 2004 & Compulsory & 13 cooperatives, 165 \\
\hline & & & Secondary, Vocational & students \\
\hline
\end{tabular}

Table 2. Entrepreneurship Education Projects in Spain's Autonomous Communities

\section{Discussion}

Having taken into account the contents and scope of the actions taken in all of Spain's Autonomous Communities, we are now able to approach a diagnosis of the state of the art of entrepreneurship education in Spain, a diagnosis that in turn we should be able to compare with the activities being carried out in this sense by other countries in our context. This assessment will provide some perspective and bring to light some of the best practices.

Until the latest University Act (LOE) came into force, only a few of the Autonomous Communities had included entrepreneurship education in their curricula as an elective subject. The pioneers in this sense were Asturias, Navarre and Castile-Leon. Since the University Act was passed, it has gradually and systematically been introduced into the curricula of all the Autonomous Communities, particularly in Vocational education (Ciclos Formativos and Formación Profesional).

Among the activities included in Table 2, sometimes the initiatives came from the schools themselves, which sought out different organizations and agencies (e.g. Chambers of Com- 
merce or Young Entrepreneurs Associations-YEA) for help in developing part of the curriculum. Certain other initiatives had their origin in the educational authorities departments of the regional administrations, which made different projects and programmes available to schools to complement already existing educational projects. Other initiatives, such as the case of Valnalón (Asturias), have been public initiatives carried out through private entities that have embarked on a new integral project to combat (and very successfully so) the deteriorated economic and employment situation of their region, and that have managed to transfer their experience to other regions.

The programmes and projects mentioned here are the result of efforts made by individuals, educators, non-profit organizations and policy-makers to improve the outlook of the educational system in Spain and to open up vital prospects for students facing an ever more competitive labour market. Some projects have not been included because they are only in the very early stages, and there may be others that we were unable to detect, but all in all this is a fairly good sampling of the programmes and activities taking place and as a first approach to entrepreneurship education in Spain.

In all, there is a good number of both curricular and extracurricular activities in all of Spain's Autonomous communities, even though in a few cases they are a matter of initiatives linked to regional strategies for fostering an enterprising culture, most of which are isolated actions that would require more scope, systematization and support in the future. With a few exceptions in which the different regional ministries involved (usually those of Education, Industry and Economy) cooperate and channel their effort through an agency charged with implementing all the entrepreneurship education activities (Asturias with Valnalón, Andalusia with the Fundación Red Andalucia Emprende, the Gabinete de Iniciativa Joven in Extremadura, or in the Basque country with Tknika), there is usually scarce coordination and cooperation among the different regional ministries with responsibilities in this matter.

One reason for this lack of coordination is that entrepreneurship education requires a multidisciplinary and cross-sectional approach that leaves it without a consolidated identity. We could say that it has an "image problem" that makes it a subject matter that is difficult to pin down, even in the areas of Education.

Until now one of the best practices observed is that of creating a public entity governed by private law (the case of Valnalón) which brings together financing and knowledge from the competent regional ministries and which acts as a valid interlocutor for municipalities and schools to collaborate in the implementation of activities that should be deployed at the different levels of local administrations. In several Autonomous Communities with more than one province this kind of activity is sometimes promoted by the town councils.

It has also been observed that in places where the actions taken by the regional ministries responsible have not yet been developed adequately, initiatives come into play from Chambers of Commerce, Young Entrepreneurs Associations (YEA), and the European Business and Innovation Centre Network (EBN). Often it is the schools themselves that directly look to these entities, as well as other private ones such as Junior Achievement, when seeking an educational offer of this type. And what on occasion is specific cooperation can sometimes turn into full 
collaboration, involving the institutional authorities and achieving a consistent programming of educational activities.

In the Autonomous Communities in which the collaboration between the regional ministries is optimal, the Chambers of Commerce, YEA and EBN do not usually address their training programmes to non-university students owing to a lack of demand. However, they do support entrepreneurs who wish to set up a business regardless of their age, such that any student seeking help and guidance to implement a business project will find it even though there are no programmed activities addressed to students as such.

In addition, it was found that not enough information is being shared horizontally (among schools or among Autonomous Communities) in relation to existing experiences in matters of entrepreneurship education; there is no centralizing agency to disseminate the best practices or encourage cooperation among the Autonomous Communities in this area.

This information deficit could be approached through a system that evaluates the outcomes of the educational system. Likewise, best practices could be reported and exchanged through the organization of forums or periodical seminars among those responsible for the areas of education and industry in the different Autonomous Communities. This type of forum could also be promoted or fostered jointly from the Ministries of Industry and of Education. Recall that political commitments were made, including the evaluation of the progress made by member States in entrepreneurship education, as a the result of the 2006 Oslo Agenda, as well as other EU documents.

In regard to the dissemination of information, the impulse in horizontal information about experiences in entrepreneurship education has come from Valnalón in Asturias, which has taken the initiative on numerous occasions to transfer their educational project to other Autonomous Communities. This has meant that their own programmes (EME, EJE, JES, etc.) can be found in other Autonomous Communities (Andalusia, Canary Islands, Extremadura, Navarre and the Basque Country) where they have been successfully applied. The DG for SMEs has also contributed to making known these and other best practices in European and national contexts.

Another positive aspect to be highlighted in this review is the creation of entrepreneurship "seedbeds" in schools, in EBNs, and exceptionally in some Chambers of Commerce (Las Palmas de Gran Canaria). The seedbeds are one of the best ways to bring the business world together with education. They not only play an important role as a vehicle for the "demonstration effect" but also a follow-up can be made of the businesses created within them, facilitating assessment of the activities carried out according to their business performance, especially in the context of vocational training.

There are indications that point to these seedbeds as a great success in regard to student participation (especially in vocational training), because students can experience first-hand the creation of an enterprise, and find support from their tutors for launching it if the prospects for success are favourable. The economic success obtained by many of these companies serves to encourage other students to follow their example and put aside their fears about creating an enterprise, not to mention the economic benefit it provides for the region. 
The itinerary for entrepreneurship education should begin in Early Childhood and Primary Education, and culminate in an entrepreneurial seedbed, where students who so desire can launch a business project and count on the necessary support until the enterprise has reached maturity. Entrepreneurial seedbeds exist in all of Spain's Autonomous Communities, although not all of them are linked to the educational system. The experience of Tknika and the Urratsbat program in the Basque Country, where companies started from seedbeds have been followed up since 2007, found that 136 of these enterprises are not only still in business but in 2007 had a turnover worth $€ 5,000,000$. This experience shows the profitability that can come from institutional investment in entrepreneurship education, and the production and employment that can result from these companies born of entrepreneurial seedbeds.

In short, the ability to launch entrepreneurial projects has gradually been gaining much deserved prominence in recent years, both on the national and international economic agendas, for two reasons: on one hand, owing to its vital importance in fostering the competitiveness of human capital, and therefore the productive fabric of the country, and on the other, because of its ability to create employment. Enterprises not only create employment but also social stability, and therefore entrepreneurship should be stimulated from all possible angles if we wish to fight unemployment and generate wealth in a modern economy. It is well known that enterprising individuals tend to perceive market opportunities in their environment that they can develop successfully where others may see only risk.

Thus, given the context of the globalized knowledge economy we find ourselves immersed in, it seems logical to enrich its field of action for the benefit of all. The attitude we take towards entrepreneurship education will have a large impact on economic growth in Spain, because it promotes both individual creativity and economic dynamism. The creation of new enterprises, the commercialization of new ideas and innovation are essential for the economy.

It is therefore necessary to coordinate the financial and personal efforts of the different Administrations involved; they in turn must also improve communication and structures among themselves with periodic meetings and/or specialized publications. It is also necessary to devote greater effort to motivating, training and rewarding teachers and schools, because the specification of the curriculum and the inclusion of this type of subject matter in the school's educational project depends on the will of the teaching staff. Teachers should therefore be the first objective of entrepreneurship education because they really are the first and most important link in the educational chain.

\section{Author details}

José C. Sánchez-García* and Brizeida Hernández-Sánchez

*Address all correspondence to: jsanchez@usal.es

Chair of Entrepreneurship, Salamanca University, Salamanca, Spain 


\section{References}

[1] Sánchez, J.C., Aldana R., \& Hernández B.R. (2013) Activities and programs of entrepreneurship education in Spain. American Journal of Entrepreneurship, 6(2), 73-93.

[2] Eurodyce (2012). Entrepreneurship education at school in Europe: National Strategies, Curricula and Learning Outcomes

[3] Dirección General de Política de la Pequeña y Mediana Empresa (2010). El fomento de la iniciativa emprendedora en el sistema educativo en España. Madrid

[4] Sánchez, J.C. (2011). University training for entrepreneurial competencies: Its impact on intention of venture creation. International Entrepreneurship and Management Journal, (7), 239-254

[5] Sánchez, J.C. (2013) The Impact of an Entrepreneurship Education Program on Entrepreneurial Competencies and Intention. Journal of Small Business Management, 447-465

[6] Global Entrepreneurship Monitor. GEM. http://www.gemconsortium.org (accesed 9 February 2015)

[7] European Commission.Enterprise and Industry. http://ec.europa.eu/enterprise/entrepreneurship/training_en.htm (accesed 6 February 2015)

[8] European Council. Council of the European Union. Presidency Conclusions. Lisbon European Council. http://consilium.europa.eu/ueDocs/cms_Data/docs/ pressData/en/ec/00100-r1.en0.htm (accesed 5 February 2015)

[9] European Commission. Enterprise and Industry. Industrial competitiveness. http:// ec.europa.eu/enterprise/enterprise_policy/charter/docs/charter_es.pdf (accesed 5 February 2015)

[10] Direction Generale de Entreprises. DGE. http://www.industrie.gouv.fr/pratique/ format/colloq/sp_coll-es.htm (accesed 5 February 2015)

[11] European Commission. Enterprise and Industry. Industrial Policy communication. http://ec.europa.eu/enterprise/enterprise_policy/mult_entr_programme/ programme_2001_2005.htm (accesed 5 February 2015)

[12] European Council. Council of the European Union. http://www.consilium.europa.eu/ uedocs/cms_data/docs/pressdata/en/ec/104692.pdf (accesed 5 February 2015)

[13] European Commission. Enterprise and Industry. Industrial Policy communication http://ec.europa.eu/enterprise/entrepreneurship/support_measures/training_education/archives.htm (accesed 5 February 2015).

[14] European Commission. Enterprise and Industry. Industrial Policy communication. Training Education. http://ec.europa.eu/enterprise/entrepreneurship/support_measures/training_education/primsecedu.htm (accesed 6 February 2015) 
[15] European Commission. Enterprise and Industry. Entrepreneurship. http://ec.europa.eu/enterprise/entrepreneurship/support_measures/training_education/minicomp.htm (accesed 6 February 2015)

[16] Comisión de las Comunidades Europeas. Comunicación de la Comisión. Educación y Formación 2010. http://eur-lex.europa.eu/LexUriServ/LexUriServ.do?uri=COM: 2003:0685:FIN:ES:PDF (accesed 6 February 2015)

[17] European Commission. Enterprise and Industry. Industrial Policy communication. Training Education http://ec.europa.eu/enterprise/entrepreneurship/support_measures/training_education/commplan.htm (accesed 6 February 2015)

[18] European Commission. Enterprise and Industry. Entrepreneurship. http://ec.europa.eu/enterprise/entrepreneurship/support_measures/training_education/oslo.htm (accesed 6 February 2015)

[19] European Commission. Enterprise and Industry. http://ec.europa.eu/enterprise/policies/sme/files/smes/vocational/entr_voca_es.pdf. (accesed 6 February 2015)

[20] Official Journal of the European parliament, L 394/10. 30.12.2006. http://eur-lex.europa.eu/LexUriServ/LexUriServ.do?uri=OJ:L:2006:394:0010:0018:ES:PDF (accesed 8 February 2015)

[21] These eight key competencies are the ones included in the minimum guidelines for teaching established in Spain by the application of Art. 6.2 Law of Education (LOE)

[22] European Commission. Enterprise and Industry. http://ec.europa.eu/enterprise/ entrepreneurship/sba_en.htm (accesed 2 February 2015)

[23] Junior Achievement. http://www.fundacionjaes.org (accesed 9 February 2015). 
